\title{
Effect of Incarceration on Well Being of Prisoners: A Study among Convicted and Undertrials
}

\author{
Om Prakash ${ }^{1}$, Neelu Sharma ${ }^{2}$, Amool Ranjan Singh ${ }^{3}$, Kaptan Singh Sanger ${ }^{4}$
}

\section{ABSTRACT}

Well being is state of physical, psychological, emotional and social happiness as a whole. Present study intends to assess the effect of imprisonment on the general well being of prisoners. Two groups of prisoners: convicted and under trials were selected by purposive sampling technique from Birsa Munda Central Jail, Hotwar, Ranchi, India. Among eighty six prisoners thirty six were convicted and fifty were under trials. Both the groups of criminals were matched on various socio-demographic parameters such as: gender, age, education, religion, marital status, residence and occupation. All participants were assessed on PGI General Well Being Measure (Verma \& Verma, 1989). Obtained responses were scored by using standard scoring procedures and subsequently statistically analyzed by using Chi-square and t- test. In current study both group have shown poor general well being. Though, the prisoners of under trial group were more impaired on well being measure in comparison to convicted criminal's group.

Keywords: Incarceration, Well Being, Prisoners, Convicted, Undertrial, Criminals

The effects of incarceration on the well being of prisoners have been under researched part of prison organization. Now day emerging inclination in behavioral scientists is to study the effect of incarceration on the well being of criminals. Over crowdedness, lack of basic amenities, physical and psychological trouble, clash between groups of prisoners is the worldwide problem of prisons.

Prisoners are more susceptible for poor well being due to number of reasons. First of all those who have committed severe crimes such as murder, robbery and rape are punished by court and they have to reside in prison for long period of time. At the entrance of jail they get estranged from their family and they know they have to wait for the long period of time to obtain reunion with the family. After family we get support, happiness, company, help, recommendation and many more from our friends. But in the case of criminals' imprisonment grab this support system

\footnotetext{
${ }^{1}$ Clinical Psychologist, GMCH Sector-32 Chandigarh, India.

${ }^{2}$ PhD Scholar, RINPAS, Kanke, Ranchi, India.

${ }^{3}$ Professor \& HOD, Department of Clinical Psychology, RINPAS, Kanke, Ranchi, India.

${ }^{4}$ Additional Professor, Department of Clinical Psychology, RINPAS, Kanke, Ranchi, India. *Corresponding Author

(C) 2015 I O Prakash, N Sharma, A Singh, K Sanger; licensee IJIP. This is an Open Access Research distributed under the terms of the Creative Commons Attribution License (http://creativecommons.org/licenses/by/2.0), which permits unrestricted use, distribution, and reproduction in any Medium, provided the original work is properly cited.
} 


\section{Effect of Incarceration on Well Being of Prisoners: A Study among Convicted and Undertrials}

from them. This isolation leaves most damaging effect on prisoners then the jail setting (Yang et al., 2009; Mackenzie \& Mitchell, 2005).

Living environment is one of components of well being which is found to be unhygienic, restricted, overfull in many prisons. As a result of increase in numbers of crime and criminals, prisons are now overcrowded in many countries. Crowding instigates aggressive and hostile behavior in prisoners, it is found in numerous studies (Cox, Paulus, \& Mc Cain, 1984; Paulus \& McCain, 1983), and violence in prisons is also increasing day by day (Kimmett, O’Donnell, \& Martin, 2002; Mc Corkle, 1992). Overcrowding in prisons has been also found to be connected with the decrease in psychological wellbeing of the inmates (Lawrence \& Andrews, 2004; Lepore, Evans, \& Schneider, 1991).

Well being is a subjective feeling of happiness, fulfillment, and usefulness in personal and social front, success, and support in different aspects of life. Well being is a subjective phenomenon. Sometimes we see the people who are facing the extremely adverse situation in their lives but they are happy with the positive outlook of life and their well being in term of physical, emotional, psychological is intact. World Health Organization (1948) defined health as "a state of complete physical, mental and social well-being and not merely the absence of disease or infirmity"

Well-being is a concept which is originated from the positive psychology. Positive psychology emphasizes to explore and study the perfection in the lives of human beings. Well being is a term which identify goodness in variety of spares of life such as ability to cope with life situations, feeling of worth for others, living in and take pleasure in life and many more (Singh \& Shyam, 2007).

Hence, well-being tend to achieve the goal of World Health Organization "healthy mind in a healthy body in a healthy environment” (Shri, 2007).

Lack of proper nutrition make their physical health poor, fights, violence, conflict between groups or gangs of prisoners deteriorate their physical and psychological health as well. Furthermore stigmatization by the society frightened the prisoners about their future. All these conditions gradually and finally contributes to prisoners poor well being in term of growth of frustration, stigma, depression, anxiety, insecurity, feeling inferiority, feeling of worthlessness, guilt, shame and in some cases results in suicide (Levenson \& Cotter 2005; Tewksbury 2005; Levenson 2003; Schnittker \& John, 2007; Dye 2010).

In Indian prisons prisoner's condition is more or less similar or worse like other developing countries. There are some common problems across Indian prisons. Overcrowding, unhygienic and unhealthy living conditions, prolonged detention of under trial prisoners, limited and inadequate treatment facilities, claim of inhumane attitude and behavior of prison officials have 


\section{Effect of Incarceration on Well Being of Prisoners: A Study among Convicted and Undertrials}

involved attention of many critics in recent years ( Neier 1991; National Crime Record Bureau 2005 \&_Bellad et al, 2007).

Kazi et al, (2010) mention that prisons are the ideal place for infectious diseases screening and intervention given the condition of poverty and drug addiction.

There is dearth of research which represent the status of well being of convicted and under trial criminals. The reason at the back of this shortage of studies is in particulars that in developed country may be under trial prisoners reside in prison for very short period of time. Judiciary system in these countries is fast and cases gets judgment on speedy trial system. In India and other developing countries situation is somewhat different.

Examining the Central Jail (Tihar), Sneha and Garg (2012) have find out some shocking facts about extend imprisonment of under trail prisoners. They state that in 1993, out of the 7200 prisoners residence in the Central Jail Complex (Tihar Jail, Delhi), merely 900 prisoners were actually convicted for any crime. Seven out of every eight prisoners in Tihar Jail comprise of them who had not been convicted for any crime and its sum total was about to $90 \%$ of all prisoners. The more shocking fact was out of 280 women prisoners, only 20 had been convicted. Sometimes under trial prisoners served in prison comparatively long that they would have been served for their crime by law (Sneha \& Garg, 2012).

Earlier researches states that imprisonment leaves negative effect on the psychological and physical health of the prisoners and deteriorates their mental balance. Some negative effects are depression (Singh \& Verma 1976; Cooper 1974; Walker 1983) emotional withdrawal (Clements, 1979), suicidal thoughts or actions (Flanagan, 1980) and increasing levels of hostility (Bolton et al, 1976).

Cohen \& Taylor (1972) state that prisoners who are imprisoned from long time they develop obsessive fear of deterioration. Though some other studies around this time found that prisoners don't seen imprisonment as threat to their psychological health (Richards, 1978) Some examiner found imprisonment increases verbal intelligence(Bolton et al1976).

The opinion of researchers is diverse about the effect of imprisonment on the well being of prisoners, but maximum studies which is done on the general psychological impact of incarceration says that inmates experience major trouble at the start of the punishment ( MacKenzie and Goldstein, 1985; Sapsford, 1978).

In view of above research findings and dearth of studies of well being status of prisoners, especially under trial prisoners present study was planned to assess the well being of convicted and under trial criminals and interpret the difference between their well being . 


\section{METHODS}

\section{Aim}

Present study intended to see the effect of imprisonment on the general well being of convicted and under trial prisoners on PGI General Well Being Measure.

\section{Design}

This was cross sectional study consist two groups: convicted criminals group and under trial criminals group.

\section{Sample}

Study consist eighty six samples. In which thirty six were convicted criminals and fifty were under trial criminals. Both the groups were comprised of offenders involved in different crimes such as murder, rape and robbery, fraud, stealing. Samples were selected from Birsa Munda Central Jail, Hotwar Ranchi, India based on the purposive sampling; criteria of sample selection were -aged 25-45 years, educated up to $10^{\text {th }}$ Std. They had to be able to give the informed consent to participate in the study.

\section{Tools}

\section{Socio-Demographic:}

This is a semi structured Performa. It contains information about socio demographic variables such as age, sex, religion, education, marital status, domicile and occupation of the subjects.

\section{PGI General Well Being Measure}

Verma \& Verma (1989) developed PGI General Well-being scale to assess the general wellbeing of the subjects. The scale consisted of 20 items. Each item is rated on a four-point scale indicating personal frequency of occurrence (not at all, rarely, often or most of the time, frequency or all the time). Higher total scores indicate higher levels of well-being.

The split-half coefficient of reliability corrected by Kudar Richardson correlation (20) was found to be .98 (Verma, Dubey and Gupta, 1983). It is found to have satisfactory validity and highly significant reliability i.e. K. R. 98 and discriminative value.

\section{PROCEDURE}

Sociodemographic information was collected using Socio Demographic Data Sheet. PGI General Well Being Measure was administered upon both the groups to assess their well being in prison.

\section{Statistical Analysis}

The results were analyzed using statistical package SPSS-version 20. Socio-demographic variables of both the groups were analyzed and compared using chi ${ }^{2}$ test. Age and performance of both the groups on PGI-General Well Being Measure was analyzed by using t-test. 


\section{Effect of Incarceration on Well Being of Prisoners: A Study among Convicted and Undertrials}

\section{RESULT}

The demographic data of both the groups are given in Table 1. There were no significant differences found in any socio-demographic variable between both the groups. Table: 2 shows result on age variable of convicted and under trial groups of criminals. On age variable under trial group's $\mathrm{M}+\mathrm{SD}=36.64 \pm 7.78$, however convicted criminal's $\mathrm{M}+\mathrm{SD}=37.16 \pm 9.81$. Further, t-score of .277 ( $>>.05)$ reveals there was no significant difference between the both groups on age variable.

Table: 3 present results of both the groups on PGI General Well Being Measure. On PGIGWM under trail group $\mathrm{M} \pm \mathrm{SD}=11.28 \pm 3.87$ and convicted group's $\mathrm{M} \pm \mathrm{SD}=13.77 \pm 3.83$. Further, t-score of 3.10 ( $\mathrm{p} \leq .01)$ suggests significant difference between both the groups on PGIGWM.

\section{DISCUSSION}

Present study was designed to explore the effect of imprisonment on the general well being of prisoners and see the difference between well being of prisoners. In current study criminals were divided in two groups: convicted and under trial to interpret the effect of incarceration on their general well being. Present study found that under trial offender's group attain lower on the PGIGWM in comparison to the convicted group. Which suggest under trial's poor well being in comparison to the convicted criminal's group.

One reason behind poor general well being of under trial's , they are imprisoned in allegation of committing crime which is not yet to be proved or not proved by judiciary . In this way they survive in prison environment for less time period than the convicted prisoners. They face separation from the family and friends, lack of social support, paucity of recreational events, restricted environment of jail, poor diet and many more troubles which gradually deteriorate their well being (Yang et al., 2009; Mackenzie \& Mitchell, 2005). Previously done studies says well being of prisoners gets deteriorated at the beginning of the imprisonment (Mackenzie \& Goldstein, 1985; Sapsford, 1978). These findings are in agreement of the present study as under trial's well being was more impaired.

Many studies demonstrate consistency with the findings of the present study. One review done by Sneha \& Garg (2012) on Tihar Jail inmates which reports that under trial prisoners were detained in prison for a long period of time, (some times more than the period if they would be sentenced by law) faces many physical and mental difficulties. Khurana \& Dhar (2000) also reported based on their study; if under trial period gets extend for months or years then it affect negatively mental state of under trial prisoners and their condition become terrible. They further state that the tough life in prison worsens the situation and deteriorate quality of life and subjective well-being of under trial prisoners. Many times they become mentally ill. In present study well being of under trials was also impaired as some prisoners were placed in prison as of relatively lengthy period of time. As the trial period gets longer under trial's experience more 


\section{Effect of Incarceration on Well Being of Prisoners: A Study among Convicted and Undertrials}

helplessness, hopelessness and uncertainty about their release. This condition develop conundrum like situation for the under trial's which damage their well being more than the convicted prisoners.

Earlier researchers conclude that by the course of time prisoners adapt the prison environment and become adjusted (Zamble, 1992). Adjustment is an ability of individual which enable them to cope up with the life situation whether good or bad. Khurana and Dhar (2012) found in their study that under trial's had high level of anxiety and stress and religious practices, yoga and meditation reduces stress and improves their mental health. These outcome shows conformity with the findings of present study as under trial's have shown poor well being than the convicted prisoners. This may be because convicted criminals live in prison from long time and they develop coping strategy (MacKenzie \& Goldstein, 1985) to deal with the jail environment stressor which under trial's lack due to the new entry at jail and have more impaired well being than the convicted prisoners. Though, there is a need of more researches on this matter.

However, present study is opposing up to some degree the findings of the previous studies which reveals that prisoners who have spent more time behind the bars has poor well being (Schnittker \& John 2007). These studies reports that these prisoner struggles with themselves to maintain their self esteem and self image in prison, which signify their poor well being in comparison to them who live in prison for short time period (Jordan Picken ,2012; Mckenzi \& Goldstien,1985). Also it has been found in research that newly arrived inmates, who are probable to serve long term punishment they suffer more from stress (MacKenzie and Goldstein, 1985) in comparison to those prisoners who are residing from lengthy period of time in jail. However this matter is needed to explore more in future studies. These inconsistencies with the past researches may be due to the differences in methodology between the present and past studies because current study is a small sample study.

Under trial prisoners develop psychiatric morbidity in trial periods (Sharma et. al, 2014). Prisoners experience numerous stressors which comprise separation from their family members, overcrowding (Lawrence \& Andrews, 2004; Lepore, Evans, \& Schneider, 1991) lack of sensory stimulation, contact with hard-core criminals, and qualms on trial period and release, worries about future, fear, and frustration are commonly experience by prisoners. The trial period is great stress to under trials. Thrashing of prestige in society, insecurity of outcome of the court trial, sentence panic, environmental problem such as residing in jail and the loss of monetary resources effects negatively and specifically under trial prisoners (Khurana \& Dhar, 2012), and finally devastate well beings of the prisoners.

\section{CONCLUSION}

Present study was designed to assess the effect of imprisonment on general wellbeing of under trial and convicted criminals and interpret is there any difference between their well being .We can then conclude that imprisonment damage general well being of prisoners because both the 


\section{Effect of Incarceration on Well Being of Prisoners: A Study among Convicted and Undertrials}

groups of prisoners perform poorly on the well being measure. However, under trial criminal's group have revealed poor general well being than the convicted group.

\section{RECOMMENDATIONS}

Small sample size was a limitation of the present study. The female population was excluded from the study thus limiting its generalization. Future studies can compare the performance of male and female prisoners on well being with the combination of some other variables e.g. personality features, effect on the well being of families and many more.

\section{ACKNOWLWDGEMENT}

We are extremely thankful to the Superintendent of Hotwar Central Jail (Ranchi, Jharkhand, India) for his enormous support in conducting this study. We thank all the staff and inmates of the prison for their cooperation in completion of this study.

\section{REFERENCES}

Bellad, A. A., Naik, V. A., \& Mallapur, M. D. (2007). Morbidity pattern among prisoners of central jail, Hindalga, Belgaum, Karnataka. Indian Journal of Community Medicine, 32(4), 307.

Bolton, N., Smith, F. V., Heskin, K. J., \& Banister, P. A. (1976). Psychological correlates of long-term imprisonment: IV. A longitudinal analysis. The British Journal of Criminology, 38-47.

Clements, C. B. (1979). Crowded prisons. Law and Human Behavior, 3(3), 217-225.

Cohen, S., \& Taylor, L. (1972). Psychological survival: The experience of long-term imprisonment. Harmondsworth: Penguin.

Cooper, H. H. (1974). The all-pervading depression and violence of prison life.International Journal of Offender Therapy and Comparative Criminology.

Cox, V. C., Paulus, P. B., \& McCain, G. (1984). Prison crowding research: The relevance for prison housing standards and a general approach regarding crowding phenomena. American Psychologist, 39(10), 1148.

Dye, M. H. (2010). Deprivation, importation, and prison suicide: Combined effects of institutional conditions and inmate composition. Journal of Criminal Justice, 38(4), 796806.

Flanagan, T. J. (1980). The pains of long-term imprisonment: A comparison of British and American perspectives. The British Journal of Criminology, 148-156.

Kazi, A. M., Shah, S. A., Jenkins, C. A., Shepherd, B. E., \& Vermund, S. H. (2010). Risk factors and prevalence of tuberculosis, human immunodeficiency virus, syphilis, hepatitis B virus, and hepatitis $\mathrm{C}$ virus among prisoners in Pakistan. International Journal of Infectious Diseases, 14, e60-e66.

Khurana, A. and Dhar, P. L (2000). Final report submitted to Vipassana Research Institute. Indian Institute of Technology, New Delhi. 


\section{Effect of Incarceration on Well Being of Prisoners: A Study among Convicted and Undertrials}

Kimmett, E., O’Donnell, I., \& Martin, C. (2002). Prison violence. The dynamics of conflict, fear and power.

Lawrence, C., \& Andrews, K. (2004). The influence of perceived prison crowding on male inmates' perception of aggressive events. Aggressive behavior, 30(4), 273-283.

Lawrence, C., \& Andrews, K. (2004). The influence of perceived prison crowding on male inmates' perception of aggressive events. Aggressive behavior, 30(4), 273-283.

Lawrence, C., \& Andrews, K. (2004). The influence of perceived prison crowding on male inmates' perception of aggressive events. Aggressive behavior, 30(4), 273-283.

Lepore, S. J., Evans, G. W., \& Schneider, M. L. (1991). Dynamic role of social support in the link between chronic stress and psychological distress. Journal of personality and social psychology, 61(6), 899.

Lepore, S. J., Evans, G. W., \& Schneider, M. L. (1991). Dynamic role of social support in the link between chronic stress and psychological distress. Journal of personality and social psychology, 61(6), 899.

Levenson, J. S. (2003). Community notification and civil commitment of sex offenders: A review of policies designed to combat sexual violence. Journal of Child Sexual Abuse, 12(3/4), 17-52.

Levenson, J. S., \& Cotter, L. P. (2005). The effect of Megan's Law on sex offender reintegration. Journal of Contemporary Criminal Justice, 21(1), 49-66.

Mackenzie, D. L., \& Goodstein, L. (1985). Long-Term Incarceration Impacts and Characteristics of Long-Term Offenders An Empirical Analysis. Criminal Justice and Behavior, 12(4), 395-414.

MacKenzie, D. L., \& Mitchell, F. N. (2005). Inmates' Experiences in Prisons: Different Perspectives. Journal of Contemporary Criminal Justice, 21(4), 309.

McCorkle, R. C. (1992). Personal precautions to violence in prison. Criminal justice and behavior, 19(2), 160-173.

National Crime Record Bureau (2005). Poor spending on health care and welfare. Ministry of Home Affairs, India.

Neier, Aryeh. 1991. "Watching Rights." The Nation, 25 November.

Paulus, P. B., \& McCain, G. (1983). Crowding in jails. Basic and Applied Social Psychology, 4(2), 89-107.

Picken, J. (2012). The coping strategies. Adjustment and well being of male inmates in the prison environment. Internet Journal of Criminology, 1-29.

Sapsford, R. J. (1978). Life-sentence prisoners: Psychological changes during sentence. The British Journal of Criminology, 128-145.

Schnittker, J., \& John, A. (2007). Enduring stigma: the long-term effects of incarceration on health. Journal of health and social behavior, 48(2), 115-130.

Schnittker, J., \& John, A. (2007). Enduring stigma: the long-term effects of incarceration on health. Journal of health and social behavior, 48(2), 115-130.

Shri, R. (2007). Well-being and alternative therapies. In R. Singh, \& R. Shyam (Eds.), Psychology of well-being (pp. 381-389). New Delhi: Global Vision Publishing House. 


\section{Effect of Incarceration on Well Being of Prisoners: A Study among Convicted and Undertrials}

Singh, G., \& Verma, H. (1976). Murder in Punjab: A psychosocial study. Indian Journal of Psychiatry, 18(4), 243.

Singh, R., \& Shyam, R. (2007). Psychology of well-being. New Delhi; Global Vision Publishing House.

Sneha, R. \& Garg, R. (2012). The problems of Undertrials. Criminal Law, available at http://www.legalservicesindia.com/article/article/the-problems-of-undertrials-1280-1.html

Tewksbury, R. (2005). Collateral consequences of sex offender registration. Journal of Contemporary Criminal Justice, 21(1), 67-81.

Verma, S. K., \& Verma, A. (1989). PGI general wellbeing measure. Lucknow: Ankur Psychological Agency.

Verma, S. K., Dubey, B. L., \& Gupta, D. (1983). PGI General Well Being Scale: Some correlates. Indian Journal of Clinical Psychology.

Walker, N. (1983). Side-effects of incarceration.British Journal of Criminology, 23, 61-71.

Yang, S., Kadouri, A., Révah-Lévy, A., Mulvey, E. P., \& Falissard, B. (2009). Doing time: a qualitative study of long-term incarceration and the impact of mental illness. International journal of law and psychiatry, 32(5), 294-303.

Zamble, E. (1992). Behavior and adaptation in long-term prisoners. Criminal Justice and Behavior, 19, 409-425

Table;1 showing socio-demographic variable of both the group

\begin{tabular}{|c|c|c|c|c|c|}
\hline \multicolumn{2}{|l|}{ Variables } & $\begin{array}{l}\text { Under Trial } \\
\text { Prisoners }\end{array}$ & $\begin{array}{l}\text { Convicted } \\
\text { Prisoners }\end{array}$ & df & $\chi^{2}$ \\
\hline \multirow{3}{*}{ Education } & 10th & 25 & 19 & \multirow{3}{*}{2} & \multirow{3}{*}{$\begin{array}{l}.433 \\
\text { (NS) }\end{array}$} \\
\hline & Intermediate & 21 & 13 & & \\
\hline & $\begin{array}{l}\text { Graduation \& } \\
\text { Above }\end{array}$ & 4 & 4 & & \\
\hline \multirow{2}{*}{$\begin{array}{l}\text { Marital } \\
\text { Status }\end{array}$} & Married & 31 & 22 & \multirow[b]{2}{*}{1} & \multirow{2}{*}{$\begin{array}{l}.007 \\
\text { (NS) }\end{array}$} \\
\hline & Unmarried & 19 & 14 & & \\
\hline \multirow{2}{*}{ Occupation } & Employed & 26 & 18 & \multirow{2}{*}{1} & \multirow{2}{*}{$\begin{array}{l}.034 \\
\text { (NS) } \\
\end{array}$} \\
\hline & Unemployed & 24 & 18 & & \\
\hline \multirow{3}{*}{ Residence } & Urban & 3 & 4 & \multirow{3}{*}{2} & \multirow{3}{*}{$\begin{array}{l}1.224 \\
\text { (NS) }\end{array}$} \\
\hline & Rural & 35 & 26 & & \\
\hline & Semi urban & 12 & 6 & & \\
\hline \multirow{4}{*}{ Religion } & Hindu & 30 & 19 & \multirow{4}{*}{3} & \multirow{4}{*}{$\begin{array}{l}.598 \\
\text { (NS) }\end{array}$} \\
\hline & Muslim & 9 & 8 & & \\
\hline & Christian & 4 & 4 & & \\
\hline & Others & 7 & 5 & & \\
\hline
\end{tabular}

NS $=$ Not Significant 
Effect of Incarceration on Well Being of Prisoners: A Study among Convicted and Undertrials

Table:2 Showing socio-demographic variable of age

\begin{tabular}{|c|c|c|c|c|}
\hline \multirow{3}{*}{ AGE } & \multicolumn{2}{|c|}{ GROUP } & \multirow[b]{2}{*}{ df } & \multirow[b]{2}{*}{$\begin{array}{l}\text { t } \\
\text { (p-value) }\end{array}$} \\
\hline & $\begin{array}{c}\text { UNDERTRIAL } \\
\text { M } \pm \text { SD }\end{array}$ & $\begin{array}{c}\text { CONVICTED } \\
\text { M } \pm \text { SD }\end{array}$ & & \\
\hline & $36.64 \pm 7.78$ & $37.16 \pm 9.81$ & 84 & $\begin{array}{l}0.277 \\
\text { (NS) }\end{array}$ \\
\hline
\end{tabular}

NS $=$ Not Significant

Table:3 Showing PGI-GWBM score of both the groups

\begin{tabular}{|c|l|l|l|l|}
\hline \multirow{2}{*}{$\begin{array}{c}\text { PGI- } \\
\text { GWBM }\end{array}$} & $\begin{array}{c}|c| \\
\text { UNDERTRIAL } \\
\text { M } \pm \text { SD }\end{array}$ & $\begin{array}{c}\text { CONVICTED } \\
\text { M } \pm \text { SD }\end{array}$ & df & $\begin{array}{l}\text { t } \\
\text { (p-value) }\end{array}$ \\
\cline { 2 - 5 } & $11.28 \pm 3.87$ & $13.77 \pm 3.88$ & 84 & 3.10 \\
& & & & $(.003)$ \\
\end{tabular}

